\title{
Reversed-phase thin-layer chromatography behavior of aldopentose derivatives
}

\author{
Dragana J. Livaja-Popović ${ }^{1}$, Eva S. Lončar ${ }^{2}$, Lidija R. Jevrić ${ }^{2}$, Radomir V. Malbaša ${ }^{2}$ \\ ${ }^{1}$ CRM Consulting, Rodenbacher Chaussee 6-Gebäude 801, D-63457 Hanau-Wolfgang, Germany \\ ${ }^{2}$ University of Novi Sad, Faculty of Technology, Novi Sad, Serbia
}

\begin{abstract}
Quantitative structure-retention relationships (QSRR) have been used to study the chromatographic behavior of some aldopentose. The behavior of aldopentose derivatives was investigated by means of reversed-phase thin-layer chromatography (RP TLC) on silica gel impregnated with paraffin oil stationary phases. Binary mixtures of methanol-water, acetone-water and dioxane-water were used as mobile phases. Retention factors, $R_{\mathrm{M}}{ }^{0}$, corresponding to zero percent organic modifier in the aqueous mobile phase was determined. Lipophilicity, $C_{0}$, was calculated as the ratio of the intercept and slope values. There was satisfactory correlation between them and $\log P$ values calculated using different theoretical procedures. Some of these correlations offer very good predicting models, which are important for a better understanding of the relationships between chemical structure and retention. The study showed that the hydrophobic parameters $R_{\mathrm{M}}{ }^{0}$ and $C_{0}$ can be used as a measures of lipophilicity of investigated compounds.
\end{abstract}

Keywords: aldopentose derivatives, QSRR-analysis, lipophilicity, RP-TLC, impregnated silica gel.

SCIENTIFIC PAPER

UDC 661.12:547.455.5:543.544.73

Hem. Ind. 66 (3) 365-372 (2012)

doi: 10.2298/HEMIND111012099L

Available online at the Journal website: http://www.ache.org.rs/HI/

The majority of biologically active compounds are chiral molecules. Monosaccharides are frequently used as starting materials in the synthesis of simpler or more complex biomolecules [1], owing to their availability and to their stereochemical, conformational and functional properties. Monosaccharide molecules contain a high density of functional groups; this enables various transformations from acyclic and/or cyclic forms. Because of their variety of functional groups these derivatives are also of chromatographic interest $[2,3]$. It is well known that the chromatographic mechanism is basically dependent on the solute size and its hydrogen bonding capability. The solute size depends on the molecular structure of the parent molecule and of the substituents existing in the molecule.

Selected derivatives of aldopentoses have conveniently been used as starting compounds and key intermediates in the synthesis of several biologically active compounds.

Lipophilicity of an investigated compound is one of the parameters, which influences its biological activity. It is a term mainly employed by medicinal chemists to describe the transport process of compounds in biological systems and is the most frequently used parameter in QSAR analysis. It is predominant descriptor of

Correspondence: L.R. Jevrić, Department of Applied and Engineering Chemistry, Faculty of Technology, University of Novi Sad, Bulevar Cara Lazara 1, 21000 Novi Sad, Serbia.

E-mail: lydija@uns.ac.rs

Paper received: 12 October, 2011

Paper accepted: 18 November, 2011 pharmacodynamic, pharmacokinetic and toxic aspects of drug activity. The lipophilic character of compounds has been defined in many ways. The hydrophobicity parameter introduced by Fujita et al. [4] has been widely accepted and defined as the logarithm of the ratio of the concentrations of an analyte in a saturated two-phase system formed by 1-octanol/water $(\log P)$. A number of methods for the calculation of log $P$ have been developed [5-7], but experimental determination still remains the most reliable. Experimental measurement of $\log P$ values by the conventional "shake flask" method is often faced with problems; besides being time consuming, the method is not applicable to very hydrophilic or very hydrophobic compounds.

Chromatographic techniques have frequently been applied in the determination of relative partition coefficients for use in quantitative relationships between chemical structure and biological activity (QSAR) [8-10]. Reverse phase thin layer chromatography and high performance liquid chromatography are used to evaluate the lipophilicity of a series of organic compounds. Chromatography is a unique method which can yield a great amount of quantitatively comparable, precise, and reproducible retention data for large sets of structurally diversified compounds. Therefore, quantitative structure-(chromatographic) retention relationships (QSRR) have been considered a model approach to establish strategy and methods of property predictions $[11,12]$. QSRR analysis appears especially attractive from the general chemometric point of view because provide the best testing of the applicability of 
individual structural parameters for property description. Currently, QSRR studies can be applied to: identify the most useful structural descriptors; predict retention for a new analyte and to identify unknown analytes; gain insight into molecular mechanism of separation operating in a given chromatographic system; quantitatively compare separation properties of individual types of chromatographic layers; evaluate properties, other than chromatographic physicochemical properties of analytes, such as lipophilicity $[13,14]$.

The aim of this methodology is to derive a model to describe the chromatographic retention on a given chromatographic system, which then can be used for future retention prediction of new solutes. Thus, when a meaningful and statistical significant model is found, no additional experiments are needed to predict the retention for new solutes.

RP-TLC provides a variety of indices (descriptors) that can be used as lipophilicity estimators. The most popular lipophilicity indices estimated by RP-TLC are derived by the $R_{\mathrm{F}}$ according to the following formula [15]:

$$
R_{M}=\log \left(\frac{1}{R_{F}}-1\right)
$$

where $R_{\mathrm{F}}$ is the retention factor calculated on the basis of migration distance of compound/migration distance of solvent front. Because $R_{\mathrm{M}}$ generally depends linearly on the concentration of the organic modifier in the mobile phase, the value has been frequently extrapolated to zero concentration of organic modifier $\left(R_{\mathrm{M}}{ }^{0}\right)$ :

$$
R_{M}=R_{M}^{0}+S \varphi
$$

where $\varphi$ is the volume fraction of organic solvent in the mobile phase, $R_{\mathrm{M}}{ }^{0}$ (intercept) is the extrapolated value obtained at $\varphi=0 \%$ modifier, and $S$ is the slope of the linear plot. The $R_{\mathrm{M}}{ }^{0}$ value is a widely used chromatographic hydrophobicity parameter. Equations (1) and
(2) are the best for deriving data for the QSRR studies.

Based on the obtained intercept and slope values of Eq. (2), another hydrophobic parameter, $C_{0}$, can be calculated:

$C_{0}=\frac{R_{M}{ }^{0}}{S}$

This hydrophobicity parameter corresponds to the parameter $\varphi_{0}$, previously defined for the HPLC method as the concentration of the organic component in the mobile phase for which the distribution of the analyzed substance between the mobile and stationary phase is equal (1:1) [16-18].

Hence, we have studied the relationship between $\log P$ and chromatographic parameters in order to examine whether RP-TLC can be utilized for $\log P$ determination of aldopentose derivatives under such circumstances.

The aim was to develop a statistical model in order to predict lipophilicity for a new solute in a satisfactory way. This would help in better understanding the separation mechanisms through the QSRR studies.

\section{EXPERIMENTAL}

Twelve derivatives of aldopentose (Table 1) were investigated. The compounds were synthesized in the laboratory of the Department of Organic Chemistry, Faculty of Sciences, University of Novi Sad [19].

The compounds were dissolved in chloroform $(2 \mathrm{mg}$ $\mathrm{cm}^{-3}$ ) and $1 \mu \mathrm{l}$ volumes of the solutions were spotted on the plates. TLC was performed on $20 \times 20 \mathrm{~cm}$ glass plates precoated with impregnated silica gel. The thinlayer of impregnated silica gel was prepared by suspending $25 \mathrm{~g}$ silica gel $60 \mathrm{GF}_{254}$ (Merck) in $100 \mathrm{ml}$ diethyl ether containing $2.5 \%$ paraffin oil. To ease the visualization, fluorescent indicator $\mathrm{F}_{254}$ (Merck) was incorporated into the layers. Impregnated silica gel layer

Table 1. Structural formulas of the examined compounds $\left(\mathrm{AC}=\left(\mathrm{CH}_{3} \mathrm{CO}-\right), \mathrm{Bn}=\left(\mathrm{C}_{6} \mathrm{H}_{5} \mathrm{CH}_{2}-\right), \mathrm{Bz}=\left(\mathrm{C}_{6} \mathrm{H}_{5} \mathrm{CO}-\right), \mathrm{Me}=\left(\mathrm{CH}_{3}-\right), \mathrm{N}_{3}=\right.$ azid $)$

1.<smiles>O=C(CC1OC(C2OCCO2)=CC1O)OCc1ccccc1</smiles>

5.<smiles>NC1C(COC(=O)c2ccccc2)OC2(OCCO2)C1OC(=O)Oc1ccccc1</smiles>

9.<smiles>[R6]OCC1OC(C#N)C(NC(=O)c2ccccc2)C1O[R6]</smiles>

2.<smiles>CC(C)(C)NC1C(O)C(COC(=O)c2ccccc2)OC12OCCO2</smiles>

6.

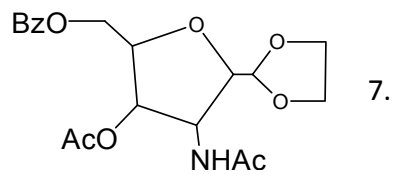

10.<smiles>[R6]OCC1OC(C#N)C2C(OC(=O)c3ccccc3)C12</smiles>

7.<smiles>NC1C(OC(=O)c2ccccc2)C(COCc2ccccc2C(=O)c2ccccc2)OC12OCCO2</smiles><smiles>O=C(NC1C(O)C(CO)OC12OCCO2)c1ccccc1</smiles>

8.<smiles>CC(=O)OCC1OC2(OCCO2)C(COC(=O)c2ccccc2)C1NC=S</smiles>

11.<smiles>CC(=O)/C=C\C1OC(COC(C)(C)C)C(OC(C)(C)C)C1NC(=O)c1ccccc1</smiles><smiles>CC(=O)/C=C\C1OC(COC(=O)c2ccccc2)C(N)C1OC(=O)c1ccccc1</smiles> 
was developed using the following mobile phases: acetone-water $(\varphi=0.5-0.7 \mathrm{v} / \mathrm{v})$, dioxane-water $(\varphi=0.5-$ $-0.7 \mathrm{v} / \mathrm{v})$ and methanol-water $(\varphi=0.5-0.7 \mathrm{v} / \mathrm{v})(5 \%$ increments) to investigate the retention parameter of the various derivatives of aldopentose.

The plates were developed to a distance of $15 \mathrm{~cm}$ by the ascending technique at room temperature with prior saturation of the chamber for 20 min with mobile phase. Dark spots were observed under UV light $(\lambda=$ $=254 \mathrm{~nm}$ ).

Ten values of $\log P$ for each solute: $A \log P_{\mathrm{s}}, A C \log P$, $A \log P, M \log P, \log P_{\text {Kow }}, X \log P_{2}, X \log P_{3}, \log P_{\text {Chem }}$ and $C$ log $P$ and $A C D \log P$ were calculated using a commercially available computer program [20-23] and are presented in Table 2.

\section{RESULTS AND DISCUSSION}

\section{Determination of $R_{M}{ }^{0}$ values and TLC equations}

Separation process in chromatography could be explained by a complex combination of the various inter- action between the solute-mobile phase and solute-stationary phase. Although no satisfactory explanation exists, quite simple intermolecular interactions make the understanding of the retention mechanism possible.

A linear relationship has been obtained between retention and concentration of organic modifier in the eluent for reversed phase chromatography, characterized by high correlation coefficients, $r$ (Eq. (2), Table $3)$. An increase in the concentration of the organic modifier led to a decrease in $R_{\mathrm{M}}$ values, i.e., the greater migration of the compounds. Constants $S$ and $R_{\mathrm{M}}{ }^{0}$ could not be determined for compounds with very low (5 and $\mathbf{9}$, in eluents with methanol) or very high (7, in eluents with doxane) $R_{\mathrm{F}}$ values.

The statistics obtained (Table 3 ) illustrate that the $R_{\mathrm{M}}{ }^{0}$ values obtained depend on the modifier used. Higher $R_{\mathrm{M}}{ }^{0}$ values were obtained for methanol (average value 3.575), than for acetone (average value 2.105) and for dioxane (average value 1.976). The higher $R_{\mathrm{M}}{ }^{0}$ values indicate greater lipophilicity.

Table 2. Partition coefficients calculated by different programs

\begin{tabular}{lcccccccccc}
\hline Com. & $A \log P_{\mathrm{s}}$ & $A C \log P$ & $A \log P$ & $M \log P$ & $\log P_{\text {Kow }}$ & $X \log P_{2}$ & $X \log P_{3}$ & $\log P_{\text {Chem }}$ & $C \log P$ & $A C D \log P$ \\
\hline 1 & 3.04 & 2.65 & 2.74 & 2.13 & 2.34 & 3.56 & 2.75 & 2.57 & 3.64 & 3.59 \\
2 & 2.29 & 1.70 & 1.89 & 1.46 & 1.42 & 2.31 & 1.97 & 1.87 & 3.04 & 3.18 \\
3 & 3.27 & 3.18 & 3.55 & 2.51 & 3.32 & 4.03 & 3.63 & 3.77 & 4.54 & 5.09 \\
4 & 2.67 & 1.67 & 2.79 & 1.80 & 1.75 & 2.56 & 2.57 & 2.72 & 3.41 & 3.77 \\
5 & 3.41 & 3.32 & 3.61 & 2.78 & 3.37 & 4.25 & 3.83 & 3.81 & 4.38 & 5.11 \\
6 & 1.07 & 0.37 & 0.28 & 0.60 & 0.02 & 0.82 & 0.51 & 0.011 & 1.39 & 1.18 \\
7 & -0.29 & -0.61 & -0.48 & -0.34 & -0.68 & -0.02 & -0.08 & -0.45 & 0.06 & -0.28 \\
8 & 3.32 & 2.34 & 1.78 & 1.25 & 2.97 & 1.85 & 3.64 & - & 2.93 & - \\
9 & 3.43 & 3.81 & 3.79 & 2.65 & 3.12 & 4.66 & 4.49 & 3.83 & 3.99 & 4.34 \\
10 & 3.36 & 3.04 & 3.34 & 2.40 & 2.09 & 3.48 & 3.31 & 3.09 & 3.45 & 3.54 \\
11 & 4.01 & 3.93 & 4.24 & 3.24 & 4.40 & 5.04 & 4.30 & 4.14 & 5.24 & 5.32 \\
12 & 4.01 & 3.93 & 4.24 & 3.24 & 4.40 & 5.04 & 4.30 & 4.14 & 5.24 & 5.32 \\
\hline
\end{tabular}

Table 3. Regression data for linear relationships $R_{M}-\varphi$ according to Eq. (2) and $C_{0}$ values of aldopentose derivatives

\begin{tabular}{|c|c|c|c|c|c|c|c|c|c|c|c|c|}
\hline \multirow{2}{*}{ Com. } & \multicolumn{4}{|c|}{ Acetone-water } & \multicolumn{4}{|c|}{ Dioxane-water } & \multicolumn{4}{|c|}{ Methanol-water } \\
\hline & $R_{\mathrm{M}}{ }^{0}$ & $S$ & $r$ & $C_{0}$ & $R_{\mathrm{M}}{ }^{0}$ & $S$ & $r$ & $C_{0}$ & $R_{\mathrm{M}}{ }^{0}$ & $S$ & $r$ & $C_{0}$ \\
\hline 1 & 2.597 & -4.680 & 0.997 & 0.554 & 2.379 & -3.880 & 0.995 & 0.613 & 4.312 & -6.198 & 0.999 & 0.695 \\
\hline 2 & 1.756 & -3.020 & 0.997 & 0.582 & 1.521 & -3.034 & 0.974 & 0.501 & 3.064 & -4.902 & 0.994 & 0.625 \\
\hline 3 & 2.389 & -3.890 & 0.999 & 0.614 & 2.129 & -3.640 & 0.991 & 0.585 & 4.298 & -6.308 & 0.997 & 0.681 \\
\hline 4 & 2.148 & -3.590 & 0.997 & 0.598 & 1.945 & -3.516 & 0.969 & 0.553 & 3.872 & -5.840 & 0.998 & 0.663 \\
\hline 5 & 2.089 & -3.382 & 0.996 & 0.617 & 1.674 & -3.046 & 0.995 & 0.549 & - & - & - & - \\
\hline 6 & 0.892 & -2.388 & 0.992 & 0.373 & 0.659 & -2.004 & 0.989 & 0.329 & 1.233 & -2.610 & 0.997 & 0.472 \\
\hline 7 & -0.030 & -1.422 & 0.986 & 0.211 & - & - & - & - & -0.054 & -0.986 & 0.971 & 0.054 \\
\hline 8 & 2.699 & -3.970 & 0.997 & 0.679 & 2.433 & -3.910 & 0.989 & 0.622 & 4.683 & -6.746 & 0.999 & 0.694 \\
\hline 9 & 2.576 & -4.112 & 0.998 & 0.626 & 2.067 & -3.718 & 0.977 & 0.556 & - & - & - & - \\
\hline 10 & 2.756 & -4.256 & 0.997 & 0.647 & 2.231 & -3.746 & 0.982 & 0.595 & 4.347 & -6.482 & 0.998 & 0.670 \\
\hline 11 & 2.745 & -4.196 & 0.999 & 0.654 & 2.552 & -4.164 & 0.990 & 0.613 & 5.222 & -7.462 & 0.998 & 0.699 \\
\hline 12 & 2.584 & -4.102 & 0.998 & 0.629 & 2.152 & -3.816 & 0.982 & 0.564 & 4.670 & -6.930 & 0.999 & 0.673 \\
\hline
\end{tabular}


The extrapolated $R_{\mathrm{M}}{ }^{0}$ values from TLC systems with different organic modifiers were correlated. The equations of these linear relationships and statistical data (correlation coefficient, $r$ and standard deviation, SD) are listed in Table 4 . These differences are most probably a consequence of the different chemical natures of the three organic modifiers and indicates that the values basicaly reflect the same molecular properties of the solute in the mobile phases used, but that these properties contribute differently to retention.

Table 4. Correlations between $R_{M}{ }^{0}$ values determined with different mobile phases; $A c=$ acetone, $D x=$ dioxane, $\mathrm{MeOH}=m e-$ thanol

\begin{tabular}{lcc}
\hline Equation & $r$ & $S D$ \\
\hline$R_{\mathrm{M}}{ }^{0} \mathrm{Ac}=0.108+0.546 R_{\mathrm{M}}{ }^{0} \mathrm{MeOH}$ & 0.988 & 0.150 \\
$R_{\mathrm{M}}{ }^{0}=0.069+0.486 R_{\mathrm{M}}{ }^{0} \mathrm{MeOH}$ & 0.982 & 0.117 \\
$R_{\mathrm{M}}{ }^{0}=-0.151+0.927 R_{\mathrm{M}}{ }^{0} \mathrm{Ac}$ & 0.974 & 0.126 \\
\hline
\end{tabular}

High correlation was obtained between the intercept $R_{\mathrm{M}}{ }^{0}$ and the slopes, $S$, values (Eq. (2)). The regression data for relationships expressed by Eq. (2), with the corresponding correlation coefficients, are listed in the Table 5. High correlation coefficients indicate that the substances investigated could be regarded as a homologous series [24].

Table 5. Equations of the relationship between $R_{M}{ }^{0}$ and slope S; $A c=$ acetone,$D x=$ dioxane, $\mathrm{MeOH}=$ methanol

\begin{tabular}{lccc}
\hline Equation & $r$ & $\mathrm{SD}$ & $\mathrm{N}$ \\
\hline$R_{\mathrm{M}}{ }^{0} \mathrm{AC}=-1.162-0.910 S$ & 0.974 & 0.205 & 12 \\
$R_{\mathrm{M}}{ }^{0} \mathrm{Dx}=-1.098-0.8795$ & 0.991 & 0.075 & 11 \\
$R_{\mathrm{M}}^{0}{ }^{0} \mathrm{MeOH}=-0.877-0.815 S$ & 0.999 & 0.072 & 10 \\
\hline
\end{tabular}

\section{Results of $\log P$ calculations}

The main purpose of this study was to use chromatographic data $\left(R_{\mathrm{M}}{ }^{0}\right)$ as descriptor of the lipophilic character of aldopentose derivatives studied. The correlation between $R_{\mathrm{M}}{ }^{0}$ values and different calculated values of $\log P$ was examined.

Ideally, regardless of a method used for calculation, all values of the calculated $\log P$ should be the same and correlation between them full $(r=1)$. A correlations check for the lipophilicity descriptors, $\log P$, was performed and the correlation matrix for variables is shown in Table 6. The method used was row-wise deletion.

The lipophilicity parameters obtained from the reversed-phase experiments, $\mathrm{R}_{M}{ }^{0}$, were compared with the calculated $\log P$ values. The correlation coefficients between $R_{\mathrm{M}}{ }^{0}$ obtained with different modifiers and $\log P$ are given in Table 7 .

By comparing the calculated values for defining the lipophilicity of the investigated molecules it is evident that methanol as a modifier gives the highest degree of correlation (calculated mean value of correlation coefficient is 0.931).

Since the correlation between $R_{\mathrm{M}}{ }^{0}$ and $\log P$ gives different correlations, an additional retention related parameter, $C_{0}$, was used. The relationship between $C_{0}$ and $\log P$ may be expressed by polynomial function. The correlation coefficients between $C_{0}$ obtained with different modifiers and $\log P$ are given in Table 8.

\section{QSRR Analysis of the investigated newly synthesized aldopentose derivatives}

In defining a QSRR model which would best explain the correlation between the retention behavior of in-

Table 6. The correlation matrix for calculated log $P$ values

\begin{tabular}{|c|c|c|c|c|c|c|c|c|c|c|}
\hline$r$ & $A \log P_{\mathrm{s}}$ & $A C \log P$ & $A \log P$ & $M \log P$ & $\log P_{\text {Kow }}$ & $X \log P_{2}$ & $X \log P_{3}$ & $\log P_{\text {Chem }}$ & $C \log P$ & $A C D \log P$ \\
\hline$A \log P_{\mathrm{s}}$ & 1 & 0.963 & 0.937 & 0.932 & 0.948 & 0.901 & 0.964 & 0.969 & 0.949 & 0.966 \\
\hline$A C \log P$ & & 1 & 0.967 & 0.968 & 0.954 & 0.969 & 0.973 & 0.973 & 0.953 & 0.945 \\
\hline$A \log P$ & & & 1 & 0.988 & 0.919 & 0.979 & 0.933 & 0.995 & 0.972 & 0.972 \\
\hline$M \log P$ & & & & 1 & 0.923 & 0.988 & 0.913 & 0.979 & 0.978 & 0.972 \\
\hline $\log P_{\text {Kow }}$ & & & & & 1 & 0.916 & 0.960 & 0.964 & 0.955 & 0.964 \\
\hline$X \log P_{2}$ & & & & & & 1 & 0.901 & 0.978 & 0.960 & 0.956 \\
\hline$X \log P_{3}$ & & & & & & & 1 & 0.988 & 0.918 & 0.951 \\
\hline $\log P_{\text {Chem }}$ & & & & & & & & 1 & 0.971 & 0.978 \\
\hline$C \log P$ & & & & & & & & & 1 & 0.991 \\
\hline$A C D \log P$ & & & & & & & & & & 1 \\
\hline
\end{tabular}

Table 7. Correlation coefficients $(r)$ between $R_{M}{ }^{0}$ and $\log P$

\begin{tabular}{lcccccccccc}
\hline$R_{\mathrm{M}}{ }^{0}$ & $A \log P_{S}$ & $A C \log P$ & $A \log P$ & $M \log P$ & $\log P_{\text {Kow }}$ & $X \log P_{2}$ & $X \log P_{3}$ & $\log P_{\text {Chem }}$ & $C \log P$ & $A C D \log P$ \\
\hline Acetone & 0.963 & 0.896 & 0.862 & 0.839 & 0.854 & 0.806 & 0.908 & 0.913 & 0.858 & 0.892 \\
Dioxane & 0.861 & 0.727 & 0.682 & 0.611 & 0.739 & 0.607 & 0.782 & 0.813 & 0.672 & 0.744 \\
Methanol & 0.986 & 0.940 & 0.908 & 0.887 & 0.919 & 0.860 & 0.967 & 0.968 & 0.915 & 0.960 \\
\hline
\end{tabular}




Table 8. Correlation coefficients $(r)$ between $C_{0} i \log P$
\begin{tabular}{lcccccccccc}
\hline$C_{0}$ & $A \log P_{s}$ & $A C \log P$ & $A \log P$ & $M \log P$ & $\log P_{\text {Kow }}$ & $X \log P_{2}$ & $X \log P_{3}$ & $\log P_{\text {Chem }}$ & $C \log P$ & $A C D \log P$ \\
\hline Acetone & 0.989 & 0.975 & 0.948 & 0.952 & 0.957 & 0.925 & 0.961 & 0.949 & 0.972 & 0.988 \\
Dioxane & 0.948 & 0.936 & 0.869 & 0.799 & 0.925 & 0.805 & 0.952 & 0.944 & 0.870 & 0.925 \\
Methanol & 0.997 & 0.981 & 0.956 & 0.978 & 0.956 & 0.946 & 0.952 & 0.930 & 0.987 & 0.989 \\
\hline
\end{tabular}

vestigated aldopentose derivatives and their structure, it was necessary to start from the simplest linear relationships. The reliability of the obtained mathematical models was estimated on the basis of the values of statistical parameters: correlation coefficient $(r)$ and standard deviation (SD).

By comparing the calculated values for defining the lipophilicity of the investigated molecules it is evident that only $A \log P_{\mathrm{s}}$ and $X \log P_{3}$ theoretical methods, gives the acceptable value correlation coefficient.

The equations expressing the relationships between lipophilicity $R_{\mathrm{M}}{ }^{0}$-Alog $P_{\mathrm{S}}$ and between $C_{0}-A \log P_{\mathrm{s}}$ and $X \log P_{3}$, with corresponding statistical parameters, are listed in Table 9.

These results lead to four conclusions. Good linear correlation was found between chromatographically determined, $R_{\mathrm{M}}{ }^{0}$, and computer calculated Alog $P_{\mathrm{S}}$ lipophilicity. The lowest values were obtained for the dioxane-water as mobile phase. Good polynominal correlation was found between $C_{0}$ and computer calculated $A \log P_{\mathrm{s}}$ (for acetone and methanol as modifiers of mobile phase) and $X \log P_{3}$ for dioxane as modifier. Results show that another retention-related measure of lipophilicity, $C_{0}$, beside $R_{\mathrm{M}}{ }^{0}$, can be used as a measure of the lipophilicity of compounds investigated.

In order to check the validity of the shown mathematical models, the calculations of the retention parameter values $R_{\mathrm{M}}{ }^{0}$ and $C_{0}$ were performed, using these equations, and their comparison with experimentally obtained data was made (Table 3).

To illustrate the prediction capabillities of the QSRR specified by Eqs. (4) and (6) the respective experimental $R_{\mathrm{M}}{ }^{0}$ data, and Eqs. (7)-(9) the respective experimental $C_{0}$ values were plotted against the calculated ones in Figures 1 and 2, respectively. The statistics obtained (Table 10) illustrate that linear equations fits satisfactorily to the experimental data.
As the slope is not different from unity, the method does not show proportional error. In addition, the value of an intercept which almost equals zero indicates the absence of systematic error and method bias.

This leads us to the conclusion that the chosen mathematical models can predict the retentive behaviour of the investigated group of newly synthesized aldopentose derivatives in a reversed-phase chromatography.

Good knowledge of quantitative correlations between a chemical structure and retention constant of newly synthesized aldopentose derivatives enables more quality conditions for their further investigation and contributes to better understanding of their structural, biological and physicochemical properties.

\section{CONCLUSION}

Twelve aldopentose derivatives were investigated by reversed-phase thin-layer chromatography on paraffin oil-impregnated silica gel plates, with acetone-water, dioxane-water and methanol-water as mobile phases. A linear relationship between $R_{\mathrm{M}}{ }^{0}$ and $S$ values was found for all mobile phases; this is a characteristic of closely related compounds. Very good correlation is found between $R_{\mathrm{M}}{ }^{0}$ of different organic modifiers. Correlations of different quality were obtaines between $R_{\mathrm{M}}{ }^{0}$ values and $\log P$ values calculated using different theoretical procedures. Very good linear correlations observed between $R_{\mathrm{M}}{ }^{0}$ values calculated by the numerical method and Alog $P_{\mathrm{s}}$ parameters, confirm that these chromatographic indices are good descriptors of hydrophobicity of test aldopentose derivatives. On the basis of this correlations, methanol-water was the best RP TLC system for determination of $\log P$. Next to $R_{\mathrm{M}}{ }^{0}$ we show that another retention related parameter $C_{0}$ can be used as alternative descriptor. The correlation between $C_{0}$ and $A \log P_{\mathrm{s}}$ (for acetone and methanol as

Table 9. Relationships between retention constants $R_{M}{ }^{0}, C_{0}$ and calculated values of Alog $P_{s}$ and Xlog $P_{3}$

\begin{tabular}{|c|c|c|c|c|c|}
\hline Mobile phase & Equation & $r$ & $S D$ & $N$ & Eq. \\
\hline Acetone-water & $R_{\mathrm{M}}{ }^{0}=0.258+0.658 A \log P_{\mathrm{s}}$ & 0.963 & 0.243 & 12 & 3 \\
\hline Dioxane-water & $R_{\mathrm{M}}{ }^{0}=0.277+0.552 A \log P_{\mathrm{s}}$ & 0.861 & 0.287 & 11 & 4 \\
\hline Methanol-water & $R_{\mathrm{M}}{ }^{0}=0.262+1.235 A \log P_{\mathrm{s}}$ & 0.986 & 0.298 & 10 & 5 \\
\hline Acetone-water & $C_{0}=0.109+0.281 A \log P_{s}-0.037\left(A \log P_{s}\right)^{2}$ & 0.989 & 0.030 & 12 & 6 \\
\hline Dioxane-water & $C_{0}=0.226+0.208 X \operatorname{LOG} P_{3}-0.029\left(X \log P_{3}\right)^{2}$ & 0.952 & 0.028 & 11 & 7 \\
\hline Methanol-water & $C_{0}=0.161+0.313 A \log P_{\mathrm{s}}-0.046\left(A \log P_{\mathrm{s}}\right)^{2}$ & 0.997 & 0.018 & 10 & 8 \\
\hline
\end{tabular}




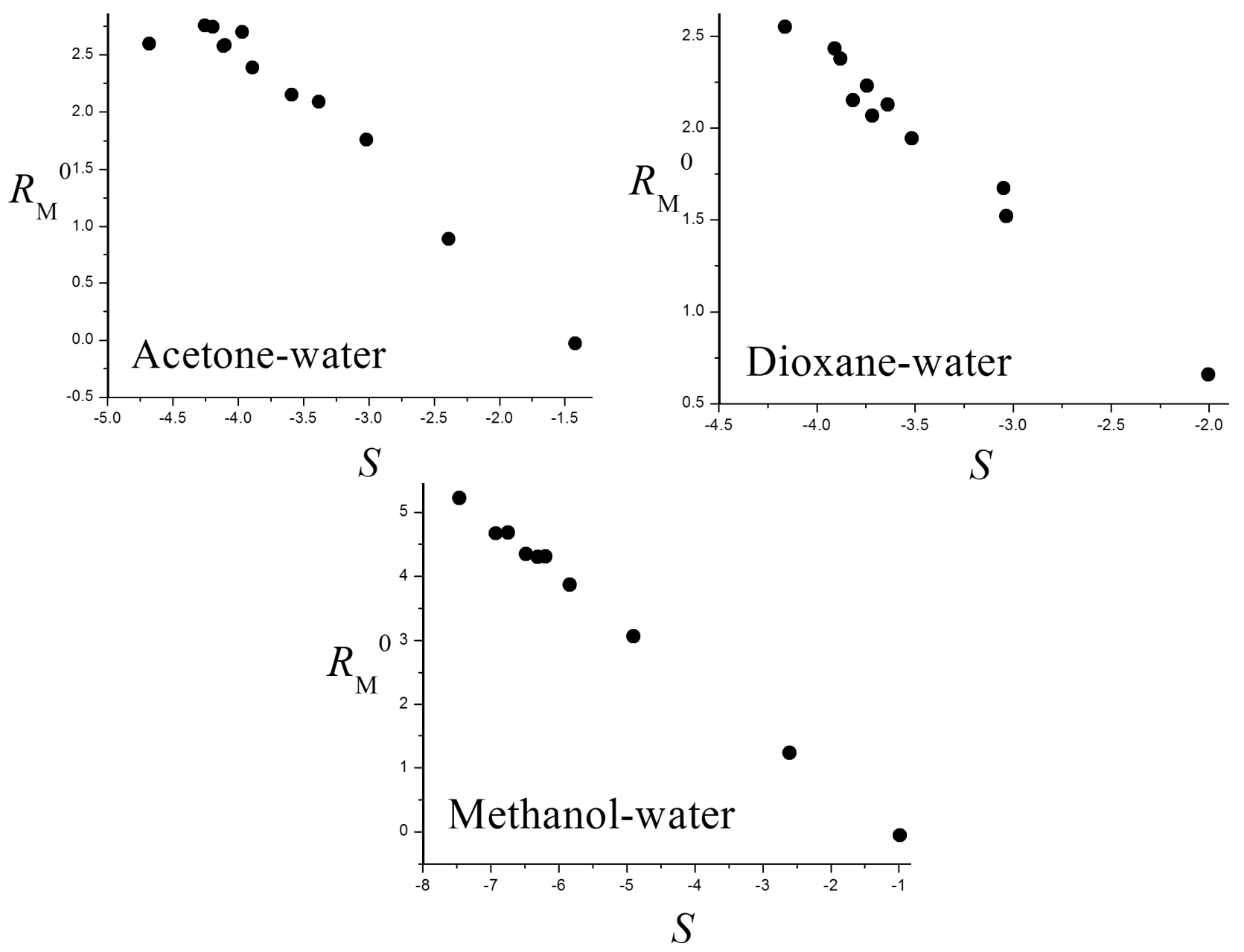

Figure 1. Correlation between experimentally obtained values and calculated values $R_{M}{ }^{0}$ on different modifiers.
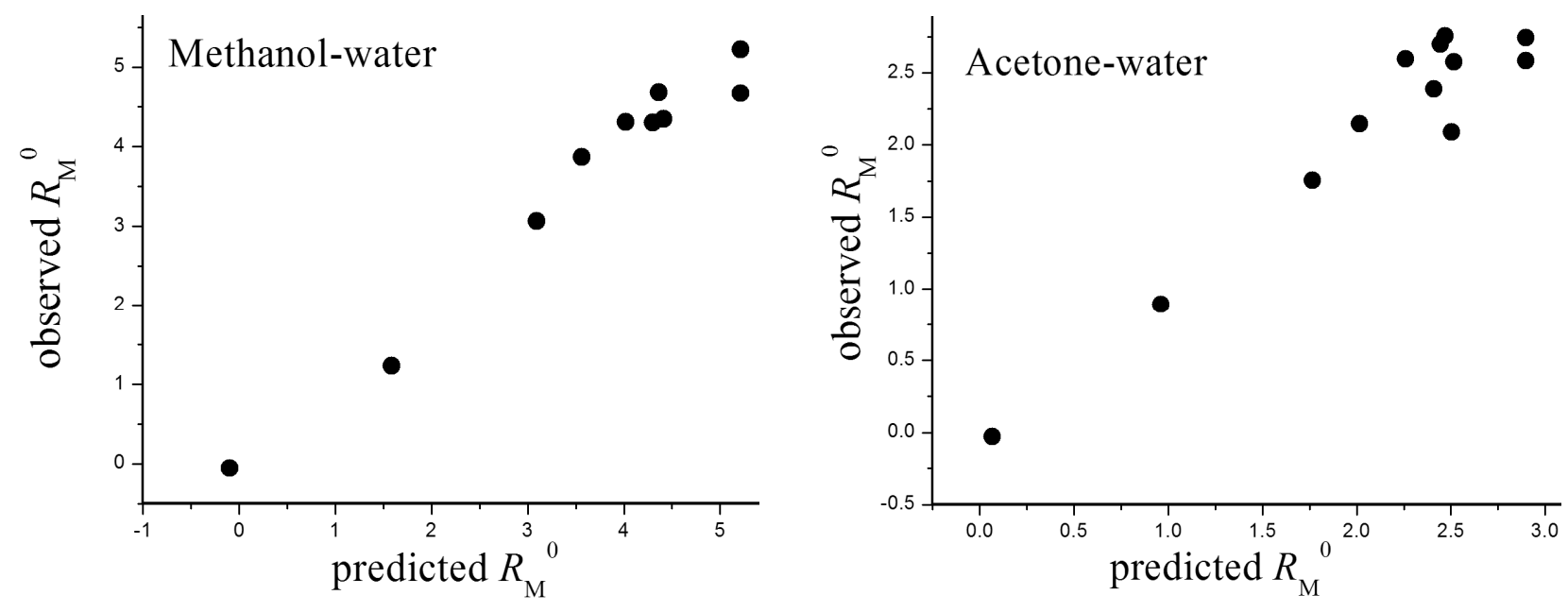

Figure 2. Correlation between experimentally obtained values and calculated values $C_{0}$ on different modifiers.

modifiers of mobile phase) and $C_{0}$ and $X \log P_{3}$ (for dioxane as modifier of mobile phase) was a polynomial function, in contrast to the linear correlation between
$R_{\mathrm{M}}{ }^{0}$ and $A \log P_{s}$. These results show that for the aldopentose derivatives investigated $C_{0}$ is a better mean of expressing lipophilicitty than the retention constant $R_{\mathrm{M}}{ }^{0}$. 
Table 10. Statitistical parameters derived from the linear regression observed vs. predicted lipophilicity parameters

\begin{tabular}{|c|c|c|c|c|c|c|}
\hline Modifier & Intercept & Slope & $R$ & $R^{2}$ & $S D$ & $P$ \\
\hline \multicolumn{7}{|c|}{$R_{\mathrm{M}}{ }^{0}$ observed vs. $R_{\mathrm{M}}{ }^{0}$ predicted } \\
\hline Acetone & $3.36 \mathrm{E}-04$ & 0.999 & 0.963 & 0.927 & 0.243 & 0.0000 \\
\hline Methanol & $-6.81 \mathrm{E}-04$ & 0.999 & 0.986 & 0.972 & 0.298 & 0.0000 \\
\hline \multicolumn{7}{|c|}{$C_{0}$ observed vs. $C_{0}$ predicted } \\
\hline Acetone & $1.99 \mathrm{E}-03$ & 0.993 & 0.988 & 0.994 & 0.003 & 0.0000 \\
\hline Methanol & $3.00 E-04$ & 0.999 & 0.997 & 0.998 & 0.017 & 0.0000 \\
\hline Dioxane & $8.06 \mathrm{E}-03$ & 0.977 & 0.952 & 0.976 & 0.026 & 0.0000 \\
\hline
\end{tabular}

\section{Acknowledgment}

This work is a part of the Project No. 114-451$-2373 / 2011$, financially supported by the Provincial Secretariat for Science and Technological Development of Vojodina and No. III-46009, supported by the Ministry Education and Science of the Republic of Serbia, 2011$-2014$.

\section{REFERENCES}

[1] S. Hanessian, A. Ugolini, P.J. Hodges, P. Beaulieu, D. Dubé, C. André, Progress in natural product chemistrz by the chiron and related approaches-synthesis of avermectin $B_{1 a}$, Pure Appl. Chem. 59 (1987) 299-316.

[2] M. Petrović, E. Lončar, M. Popsavin, V. Popsavin, Thinlayer chromatography of aldopentose and aldohexose derivatives, J. Planar Chromatogr. 10 (1997) 406-410.

[3] S.M. Petrović, E. Lončar, M. Popsavin, V. Popsavin, Retention behaviour of 1,6-anhydrohexoe and D-aldopentose derivatives on silica gel thin layers, Chem. Anal. (Warsaw) 4 (1998) 725-731.

[4] T. Fujita, J. Iwasa, C. Hansch, A New Substituent Constant, $\pi$, Derived from Partition Coefficients, J. Am. Chem. Soc. 86 (1964) 5175-5180.

[5] R. Mannhold, F.R. Rekker, C. Sonntag, M.A. ter Laak, K. Dross, E.E. Polymeropoulos, Comparative evaluation of the predictive power of calculation procedures for moleculare lipophilicity, J. Pharm. Sci. 84 (1995) 1410$-1419$.

[6] J.M. Pallicer, J. Sales, M. Rosés, C. Ràfoisc, E. Bosch, Lipophilicity assessment of basic drugs $\left(\log P_{(\mathrm{o} / \mathrm{w})}\right)$ determinated) by a chromatographic method, J. Chromatogr., A 1218 (2011) 6356-6368.

[7] J.M. Pallicer, S. Pous-Torres, J. Sales, M. Rosés, C. Ràfoisc, E. Bosch, Determination of the hydrophobicity of organic compounds measured as $\log P_{(\mathrm{o} / \mathrm{w})}$ through a new chromatographic method, J. Chromatogr., A 1217 (2010) 3026-3037.

[8] A.J.P. Martin, R.L.M. Synge, A new form of the predictive power of calculation procedures for molecular lipophilicity, J. Pharm. Sci. 84 (1995) 1410-1419.

[9] K. Héberger, Quantitative structure-(chromatographic) retentions relationships, J. Chromatogr., A 1158 (2007) 273-305.

[10] N.U. Perišić-Janjić, T.Lj. Đaković-Sekulić, S.Z. Stojanović, K.M. Penov-Gaši, HPTLC chromatography of andostene derivatives: Application of normal phase thin-layer chromatographic retention data in QSAR studies, Steroids 70 (2005) 137-144.

[11] S.M. Petrović, E. Lončar, Lj. Kolarov, V. Pejanović, Correlation between Retention and 1-Octanol-Water Partition Coefficients of some Estrane Derivatives in Reversed-Phase Thin-Layer Chromatography, J. Chromatogr. Sci. 40 (2002) 569-574.

[12] H. Noorizadeh, A. Farmany, A. Khosravi, Investigation of retention Behaviors of Essential Oils by using QSRR, J. Chin. Chem. Soc. 57 (2010) 982-991.

[13] L.R. Jevrić, G.B. Koprivica, N.M. Mišljenović, B.Ž. Jovanović, Chromatographic behavior and lipophilicity of striazine derivatives on silica gel impregnated with paraffin oil, Acta Periodica Technologica 41 (2010) 159$-168$.

[14] L.R. Jevrić, B.Ž. Jovanović, S.D. Velimirović, A.N. Tepić, G.B. Koprivica, N.M. Mišljenović, Application of lipophilicity parameters in QSRR analysis of newly synthesized $s$-triazine derivatives: Prediction of the retention behavior, Hem. Ind. 65 (2011) 533-540 (in Serbian).

[15] E.C. Bate-Smith, R.G. Westall, Chromatographic behaviour and chemical structure. Some naturally occurring phenolic substances, Biochim. Biophys. Acta 4 (1950) 427-444.

[16] K. Jazwiak, H. Szumilo, E. Soczewiński, Lipophilicity, methods of determination and its role in biological effect of chemical substances, Wiad. Chem. 55 (2001) 1047$-1074$.

[17] C. Onişor, G. Blánița, M. Coroş, M. Bucşa, M. Vlassa, C. Sárbu, A comparative study concerning chromatographic retention and computed partition coefficients of some precursors of peraza crown ethers, Cent. Eur. J. Chem. 8 (2010) 1203-1209.

[18] J. Odović, M. Aleksić, B. Stojimirović, D. Milojković-Opsenica, Ž. Tešić, Normal-phase thin-layer chromatography of some angiotensin converting enzyme (ACE) inhibitors and their metabolites, J. Serb. Chem. Soc. 74 (2009) 677-688.

[19] M. Popsavin, V. Popsavin, N. Vukojević, D. Miljković, Direct Preparation of 1,2:3,5-Di-O-cyclohexylidene- $\alpha$-Dxylofuranose from Corncobs and Its Conversion to 1-OAcetyl-2,3,5-tri-O-benzoyl-D-ribofuranose, Collect. Czech. Chem. Commun. 59 (1994) 1884-1888.

[20] C. Hansch and A.J. Leo, Substituent Constants for Correlation Analysis in Chemistry and Biology, John Wiley, New York, 1979. 
[21] J. Chou and P.C. Jurs, Computer/assisted computation of partition coefficients from molecular structures using fragment constants, J. Chem. Inf. Comput. Sci. 19 (1979) 172-178.

[22] I.V. Tetko, V.Yu. Tachuk, Application of associative neural networks for prediction of lipophilicitz in ALOGPS 2.1 program, J. Chem. Inf. Comput. Sci. 42 (2002) 1136-1145 .
[23] I.V. Tetko, V.Yu. Tachuk, Virtual Computational Chemistry Laboratory, VCC-lab 2002, http:// //146.107.217.178/servlets/vcclab?action=alogps

[24] C. Sarbu, T. Đaković-Sekulić, N. Perišić-Janjić, Evaluation of lipophilicity of some benzimidazole and benztriazole derivatives by RP HPTLC and PCA, J. Pharm. Biomed. Anal. 30 (2002) 739-745.

\title{
IZVOD
}

\section{HROMATOGRAFSKO PONAŠANJE NEKIH DERIVATA ALDOPENTOZA PRIMENOM REVERSNO-FAZNE HROMATOGRAFIJE NA TANKOM SLOJU}

\author{
Dragana J. Livaja-Popović ${ }^{1}$, Eva S. Lončar ${ }^{2}$, Lidija R. Jevrić ${ }^{2}$, Radomir V. Malbaša ${ }^{2}$ \\ ${ }^{1}$ CRM Consulting, Rodenbacher Chaussee 6-Gebäude 801, D-63457 Hanau-Wolfgang, Germany \\ ${ }^{2}$ Univerzitet u Novom Sadu, Katedra za primenjene i inženjerske hemije, Tehnološki fakultet, Novi Sad, Srbija
}

(Naučni rad)

Savremeni pristup dizajniranju novih lekova i drugih biološki aktivnih supstanci zasniva se na utvrđivanju veze između hemijske strukture jedinjenja (kvantifikovanja efekta strukturne promene) i njihove biološke aktivnosti postavljanjem preciznih matematičkih modela. Pošto je poznato da su različito supstituisani derivati aldopentoza fiziološki aktivna jedinjenja zbog izraženog antivirusnog, antibakterijskog i antitumorskog delovanja, u radu su analizirani uslovi za kvantitativna ispitivanja strukturno različito supstituisanih derivata aldopentoza i njihovog retencionog ponašanja. Retencioni mehanizam određen je upotrebom mobilnih faza aceton-voda, dioksan-voda i metanol-voda variranjem zapreminskog udela modifikatora u pokretnoj fazi. Kao nepokretna faza koristio se silika gel impregniran parafinskim uljem. Takođe je ispitan i kvalitativni kvantitativni uticaj sastava pokretne faze na retenciju. Dobre korelacije postignute su između retencione konstante, $R_{\mathrm{M}}{ }^{0}$ (retencija rastvorka u čistoj vodi) i nagiba, $S$, hromatografske jednačine. Ispitana je i primena hromatografskih retencionih parametara kao mera lipofilnosti molekula primenom QSRR analize. Za sve derivate aldopentoza definisani su deskriptori lipofilnosti izračunati primenom različitih programskih paketa: $A \log P_{\mathrm{s}}$, $A C \log P, A \log P, M \log P, \log P_{\text {Kowin }}, X \log P_{2}, X \log P_{3}, \log P_{\text {Chem }}$ i $C \log P$. Na osnovu dobijenih rezultata, razvijeni su matematički modeli koji omogućavaju procenu hromatografskog ponašanja ispitivanih molekula na osnovu njihove hemijske strukture. Definisale su se statistički značajne korelacije, koje povezuju retenciju ispitivanog molekula, $R_{\mathrm{M}}{ }^{0}$ i $C_{0}$ sa vrednostima parametara lipofilnosti. Kompletno poznavanje kvantitativnih zavisnosti između strukture i retencionih konstanti ispitivane serije derivata aldopentoza, ukazuju da hromatografski retencioni parametri realno oslikavaju složene fizičko-hemijske karakteristike molekula.
Ključne reči: Derivati aldopentoza • Hromatografija na tankom sloju • Retencioni parametar - Parametar lipofilnosti • Kvantitativna zavisnost retencija-struktura 